ORTHODONTICS

FOR DENTAL STUDENTS 


\title{
ORTHODONTICS FOR DENTAL STUDENTS
}

\author{
THIRD EDITION
}

\author{
T. C. WHITE
}

F.R.C.S., F.D.S., D.D.O. (GLASG.), F.D.S. (EDIN.), F.F.D. (IREL.)

Professor of Orthodontics and Director of Dental Education, University of Glasgow. Director of Glasgow Dental Hospital and School

\author{
J. H. GARDINER
}

B.D.s. (MANC.) D. ORTH., R.C.s. (ENG.)

Head of the Orthodontic Department, University of Sheffield Dental Hospital

\section{B. C. LEIGHTON}

M.D.S. (LOND.), F.D.S., H.D.D., D.D.O. (GLASG.) D.ORTH., R.C.S. (ENG.) Professor of Orthodontics, University of London. Head of the Orthodontic Department, King's College Hospital Dental School

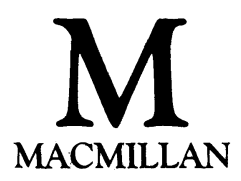


(C) T. C. White $1954,1967,1976$

(C) J. H. Gardiner 1954, 1967, 1976

(C) B. C. Leighton 1954, 1967, 1976

All rights reserved. No reproduction, copy or transmission of this publication may be made without written permission.

No paragraph of this publication may be reproduced, copied or transmitted save with written permission or in accordance with the provisions of the Copyright Act 1956 (as amended).

Any person who does any unauthorised act in relation to this publication may be liable to criminal prosecution and civil claims for damages.

First published by the Staples Press 1954

Second edition 1967

Third edition 1976

Reprinted 1983, 1985

Published by

Higher and Further Education Division

MACMILLAN PUBLISHERS LTD

Houndmills, Basingstoke, Hampshire RG21 2XS

and London

Companies and representatives

throughout the world

ISBN 978-0-333-19714-1 ISBN 978-1-349-15697-9 (eBook)

DOI 10.1007/978-1-349-15697-9 


\section{Contents}

Preface ix

1 Introduction I

Definition I

History of Orthodontics 2

Nature of Malocclusion 2

Aims of Orthodontic Treatment 3

The Need for Orthodontic Treatment 5

2 Normal Development 9

Growth and Development of the Head 9

Growth and Development of the Dental Arches 20

Normal Development of the Dental Arches 21

3 Functional Development 43

Bone Relation $\quad 43$

Tooth Relation $\quad 44$

Eruption $\quad 44$

Intra-oral Forces $\quad 46$

Occlusal Forces $\quad 53$

4 Malocclusion $\quad 58$

Malposition of Individual Teeth 60

Malrelation of the Dental Arches 64

Skeletal Morphology Unfavourable for the Production of Normal Occlusion 7 I

Classification of Malocclusion $\quad 73$

Classification of Dental Arch Relations $\quad 74$

Classification of Dental Base Relations $\quad 79$ 
Dental Base Abnormalities $\quad 82$

Pre-eruption Abnormalities $\quad 85$

6 Aetiology (continued) $\quad 98$

$\begin{array}{ll}\text { Post-eruption Abnormalities } & 98\end{array}$

7 Therapeutic Extractions and Other Surgical Procedures

Reasons for Extracting Teeth as Part of

Orthodontic Treatment

Choice of Teeth for Extraction 122

Serial Extractions $\quad$ I35

$\begin{array}{lr}\text { Surgical Treatment } & { }_{138} 8\end{array}$

8 Interceptive Measures $\quad$ I43

Care of the Deciduous Dentition $\quad$ I44

Care of the Permanent Teeth $\quad$ I49

Sucking Habits

9 Appliance Therapy in General I 55

Histological Aspect of Tooth Movement $\quad$ I 55

Changes Following the Application of Mild

Force

I 57

Changes Following the Application of Extreme

Force

162

Mechanical Appliances $\quad$ I63

Functional Appliances $\quad$ I63

The Component Parts of Mechanical Appliances $\quad$ I64

Anchorage $\quad$ I65

Methods of Delivering Pressure to Teeth I7I

Relative Advantages of Fixed and Removable

Appliances

I77

Designing an Appliance

Materials Used in the Construction of

178

Appliances

179

Soldering

I8I

Welding

182 
10 Removable and Functional Appliances

Removable Appliances in which Screws are

Incorporated

186

Removable Appliances with Auxiliary Springs

196

The Construction of Removable Appliances

Which Incorporate Mechanical Aids to Tooth

Movement Such as Screws and Springs

204

Fitting Removable Appliances 2 10

Management of Removable Appliances 2 10

Functional Appliances 2 213

Appliances Used in Functional Therapy 213

11 Fixed Appliances

Molar Bands

231

Incisor Bands

235

Attachments

Labial or Lingual Appliances

Spring or Flexible Bows

Local Fixed Appliances

Multiband Appliances

12 Examination of the Patient

General Information

$25 \mathrm{I}$

Facial Examination

252

Intra-oral Examination

256

Functional Examination

262

Aids to Diagnosis

13 Diagnosis and Treatment Planning 282

The Parents' Point of View $\quad 283$

The Dental Surgeon's Point of View $\quad 285$

Planning Treatment $\quad 286$

Planning Treatment for Various Malocclusions $\quad 290$

14 Retention After Treatment 
Bibliography $32 \mathrm{r}$

Normal Development 321

Aetiology $\quad 324$

Diagnosis $\quad 327$

Treatment Planning $\quad 328$

Histology of Tooth Movement $\quad 329$

Removable Appliances 330

Fixed Appliances $33^{\circ}$

Functional Treatment 33I

Extractions 33I

Books 332

$\begin{array}{ll}\text { Index } & 334\end{array}$ 


\section{Preface}

This text is regarded by the authors as an introduction to orthodontics and written primarily to aid the undergraduate student. It is not intended for those studying for higher qualifications but it is possible that the general dental practitioner will find assistance in the diagnosis of various orthodontic anomalies and in the treatment of at least the more simple forms. The aim of the authors remains, as in previous editions, to introduce the subject to the undergraduate in a logical manner so that the underlying principles of normal growth and development together with the causes of malocclusion and its treatment can be more readily understood. No attempt has been made to present a comprehensive picture of the whole orthodontic field and the methods of treatment that are described may not be the only means of overcoming a particular orthodontic anomaly.

This edition contains a section devoted to treatment planning of typical examples of malocclusion. It is hoped that the reader will appreciate that a broad view must be taken of this section since the infinite variation of occlusal anomalies implies that rarely are two cases exactly alike and circumstances may exist that indicate treatment methods different from those described.

No textbook can be a substitute for clinical teaching nor can any undergraduate curriculum contain sufficient time to produce a dental graduate proficient in all aspects of orthodontics but we hope that student and teacher will find some assistance from this book.

We continue to be grateful for the help and encouragement of our friends.

1976

T. C. White

J. H. Gardiner

B. C. Leighton 